\title{
Fuzzy AHP approach to prioritize enablers of green supply chain management practices: A case study of automotive component supplier
}

\author{
Himanshu Gupta ${ }^{a^{*}}$ and Mukesh Kumar Barua ${ }^{b}$
}

${ }^{a}$ Research Scholar, Department of Management Studies, Indian Institute of Technology, Roorkee, India, 247667

${ }^{b}$ Associate Professor, Department of Management Studies, Indian Institute of Technology, Roorkee, India, 247667

\section{H R O N I C L E}

Article history:

Received January 5, 2016

Received in revised format April 15,2016

Accepted May 20, 2016

Available online

May 22, 2016

Keywords:

Green Supply Chain

MSMES

AHP

Top Management

Recycling, Government

Regulation

\begin{abstract}
A B S T R A C T
With superlative growth in the number of small organizations over the past two decades, the impact caused to environment due to higher production output is also immense. Most governments are continuously taking measures to mitigate the risks associated with industrial growth. One such measure is to implement green practices throughout the supply chain. Since small organizations are important part of supply chain and a major contributor of industrial output they also need to implement green supply chain practices. This paper aims to find out important enablers for green supply chain management (GSCM) from the view point of micro small and medium enterprises (MSMEs). Fuzzy analytical hierarchy process methodology has been used to rank the enablers, three important enablers were identified viz. top management commitment and finance, government support and regulations and recycling and reuse efforts. Managers of small organizations can benefit immensely by focusing on implementing these practices in their organizations.
\end{abstract}

2016 Growing Science Ltd. All rights reserved.

\section{Introduction}

MSMEs have played a pivotal role in development of economy of any country and are often considered as powerhouse of economic growth of a country (Anand, 2015). The growth of MSMEs in developing countries especially Asian countries has been phenomenal for the past two decades. Indian MSMEs accounts for approximately $45 \%$ of industrial output and about $40 \%$ exports. These act as ancillary units for supplying by products to large enterprises. With the advent of liberalization and fierce rush to compete in global markets have often led small organizations to extensively use new and innovative technologies (Eniola \& Ektebang, 2015; Gupta \& Nanda, 2015; Gupta et al., 2015; Gupta et al., 2016; Kharub \& Sharma. 2015; Manhas et al., 2015; Sharma \& Kharub, 2015). With this desire to compete globally and with escalated production output, MSMEs have largely contributed to industrial pollution and ecological down gradation. Being an important element of supply chain of almost all industrial products, MSMEs contribution towards environmental imbalance is tremendous. With most of the past 
studies on greening the supply chain focusing on large organizations only (Beamon, 1999; Zhu \& Sarkis, 2006; Carter \& Rogers, 2008; Sarkis et al., 2011; Zhu et al., 2010; Zhu et al., 2012; Dhull \& Narwal, 2016) there needs to be studies MSMEs in this regard. There is relatively very less literature on green practices in supply chain of MSMEs. With this thought in mind this study aims at identifying the practices for successful implementation of green supply chain in MSMEs.

The rest of the paper is carved as follows, section two involves identification of literature regarding GSC implementation in context of MSMEs, section three highlights the steps of Fuzzy AHP methodology employed in this study, section four represents a case of Indian MSMEs which is an auto component supplier to large enterprise and this section also presents the results obtained through analysis, section five discusses the results and managerial implications of the study, section six consists of sensitivity analysis to check the reliability of the results, conclusions are presented in section seven and last section highlights the limitations of the study.

\subsection{Research Motives}

This study aims at:

- Identifying the important practices for GSC implementation in MSMEs through literature review,

- Prioritizing the green supply chain practices for MSMEs using fuzzy AHP,

- Discussing the managerial implications of the findings.

\section{Literature Review}

A GSC is defined as "the extension of the traditional supply chains to include activities that aims at minimizing environmental impacts of a product throughout its entire life cycle, such as green design, resource saving, harmful material reduction and product recycle or reuse". Green supply chain considers green design of the product, proper packaging, concern to resources, concern regarding waste treatment and recycling which are often ignored in traditional supply chains (Tsoulfas \& Pappis, 2006; Srivastava, 2007; Diabat et al., 2013). Many researchers have studied various practices of green supply chain implementation. Rha (2010) in his study focused on green design practices and various practices internal like management and external like government to organization. They found eco design largely improves supply chain performance also internal management has prominent role in implementation of GSCM at any organization. Sandeep et al. (2011) studied enablers of GSCM using ISM methodology and found relative advantage due to cooperation and government regulations as important enablers for GSCM implementation. Similarly Diabet and Govindan (2011) also found collaboration between product designers and suppliers and favorable government regulations as crucial enablers of GSCM implementation. Lee (2008) in their study of GSCM practices for MSMEs found buyer or customers green supply chain practices, government regulations and participation and green supply chain readiness as important factors for GSCM implementation in MSMEs. Similarly many other studies have signified the importance of various other green supply chain practices and thus identified various practices for green supply chain implementation. Few of these factors are discussed as follows:

Environmental and economic performance of an organization can be improved through substantial investment in technological advancements in terms of better machinery and equipment and use of new processes (Yu, 2007; Lin \& Hui, 2008). Employees of organization provides innovative solutions to the problems through use of technology (Digalwara \& Metri, 2004; Luthra et. al. 2013). Top management commitment is another important enabler for GSCM, top management takes care of all the activities of organization whether they are related to internal function or external functions of organization. GSCM related ideas, practices and cooperation required across organization is responsibility of top management (Zhu et al. 2007a, 2007b), success of any policy and program related to GSCM depends on top management of the organization (Lin \& Hui 2008). "Recycling is the process of collecting used products, components, and materials from the field and separating them into categories of like materials (recyclable and non-recyclable), and recyclable materials may be processed 
into recycled products, components, and materials. Reuse is the process of collecting used materials, products, or components from the field, and distributing or selling them as used". These recycling methods of which waste management is also an integral part helps in reducing the waste and also reduces the environmental impact of harmful products produced during production (Ilgin and Gupta 2010; Shrivastva, 2007). Green procurement consists of selecting various supply chain partners which includes tier 1 and tier 2 suppliers also based on their ability to follow green standards. The procurement is based on the suppliers' ability to follow these standards of eco-design and green manufacturing (Mallidis and Vlachos, 2010). Procurement is based on suppliers will to produce eco supportive components that can be easily recycled and reused (Sarkis, 2003). Suppliers are supposed to provide ideas and suggestions to produce components that impact less to the environment and thus help in implementing environmental projects (Carter and Dresner, 2001). Compliance with environmental regulation has been reported as the most important stimulator for ecological improvement in an organization (Bayliss et. al., 1998). Legislation and regulations are essential for enforcement and management of environment specific goals in an enterprise (Mudgal et. al. 2009). Government may frame environment friendly policies and may announce special benefits to those organizations implementing GSCM (Sandeep et. al. 2013). Customer awareness regarding benefits of environmental friendly products is necessary and this can be done by arranging seminars or expert talks than can motivate the customers to ask for environmental friendly products from the organizations (Luthra et al. 2013). The organizations must give some monetary benefits to customers or motivate them in some other aspects so as to enhance green purchasing among them (Sandeep et al. و 2013).

The factors identified for GSC implementation in MSMEs are listed below in Table 1.

\section{Table 1}

GSC practices enablers

\begin{tabular}{|c|c|}
\hline $\begin{array}{l}\text { Green Supply Chain } \\
\text { Practices for MSMEs }\end{array}$ & Supporting Literature \\
\hline $\begin{array}{l}\text { Technological } \\
\text { advancements (TA) }\end{array}$ & $\begin{array}{l}\text { Digalwara \& Metri, 2004; Yu, 2007; Lin \& Hui, 2008; Pawanchik \& Sulaiman, 2010; Wu } \\
\text { et al. 2010; Sarkis et al. 2011; Matus et al., 2012; Luthra et. al. 2013; Govindan et al., 2014; } \\
\text { Soda et al., 2015; Hassan et al., } 2016\end{array}$ \\
\hline $\begin{array}{l}\text { Top management } \\
\text { commitment and finance } \\
\text { (TMC) }\end{array}$ & $\begin{array}{l}\text { Digalwar \& Metri, 2004; Ravi \& Shankar, 2005; Zhu et al. 2007a, 2007b; Lin \& Hui, 2008; } \\
\text { Mudgal et al. 2009; Mudgal et al., 2010; Sarkis et al. 2011; Luthra et. al. 2013; Govindan } \\
\text { et al., 2014; Rehman et al., 2015; Soda et al., 2015; Govindan et al., } 2016\end{array}$ \\
\hline $\begin{array}{l}\text { Recycling and reuse efforts } \\
\text { (RRE) }\end{array}$ & $\begin{array}{l}\text { Shrivastva 2007; Mudgal et al. 2009; Ilgin \& Gupta 2010; Bhetja \& Babbar, 2011; Sandeep } \\
\text { et. al. 2013; Govindan et al., 2014; Prakash \& Barua, 2015; Rehman et al., 2015; Hassan } \\
\text { et al., } 2016\end{array}$ \\
\hline $\begin{array}{l}\text { Green procurement } \\
\text { strategies (GPS) }\end{array}$ & $\begin{array}{l}\text { Sarkis, 2003; Chien \& Shih, 2007; Zhu et al., 2008; Mallidis \& Vlachos, 2010; Luthra et. } \\
\text { al. 2013; Govindan et al., 2014; Lee, et al., 2014; Govindan et al., 2016; Hassan et al., } 2016\end{array}$ \\
\hline Supplier involvement (SI) & $\begin{array}{l}\text { Carter \& Dresner, 2001; Björklund et al., 2012; Sandeep et. al. 2013; Govindan et al., 2014; } \\
\text { Dhull \& Narwal, 2016; Govindan et al., } 2016\end{array}$ \\
\hline $\begin{array}{l}\text { Government support and } \\
\text { regulation (GSR) }\end{array}$ & $\begin{array}{l}\text { Bayliss et. al., 1998; Bansal \& Roth, 2000; Min \& Galle, 2001; Eiadat et al., 2008; Mudgal } \\
\text { et. al. 2009; Lopez-Gamero et al., 2011; Qi et al., 2010; Matus et al., 2012; Sandeep et. al. } \\
\text { 2013; Govindan et al., 2014; Govindan et al., 2016; Rehman et al., } 2015\end{array}$ \\
\hline Customer awareness (CA) & $\begin{array}{l}\text { Green et al., 1996; New, 2000; Zhu \& Sarkis, 2006; Mudgal et al., 2010; Eltayeb et al., } \\
\text { 2011; Luthra et al. 2013; Sandeep et al. 2013; Lee et al., 2014; Dhull \& Narwal, 2016; } \\
\text { Govindan et al., 2016 }\end{array}$ \\
\hline
\end{tabular}

\section{Methodology}

Fuzzy AHP methodology has been employed in this paper to rank the enablers of GSC practices in MSMEs based on the weights of each enabler. Prior to applying fuzzy AHP a group of eight experts were asked to meet and form a consensus on importance of each enabler over other using linguistic variables as defined in Table 2. The experts were chosen both from industry as well as academia based on the criteria of minimum ten years' experience in this field. The case of an automotive component supplier $\mathrm{ABC}$ is taken. $\mathrm{ABC}$ enterprise is one of the leading auto component supplier from Punjab and is supplier to most of the automobile companies situated in north India. The consensus approach was 
used for gathering data (Nanda et al., 2013). Fig. 1 shows a graphic map of the proposed research methodology. Fig. 1 denotes a representation of the research

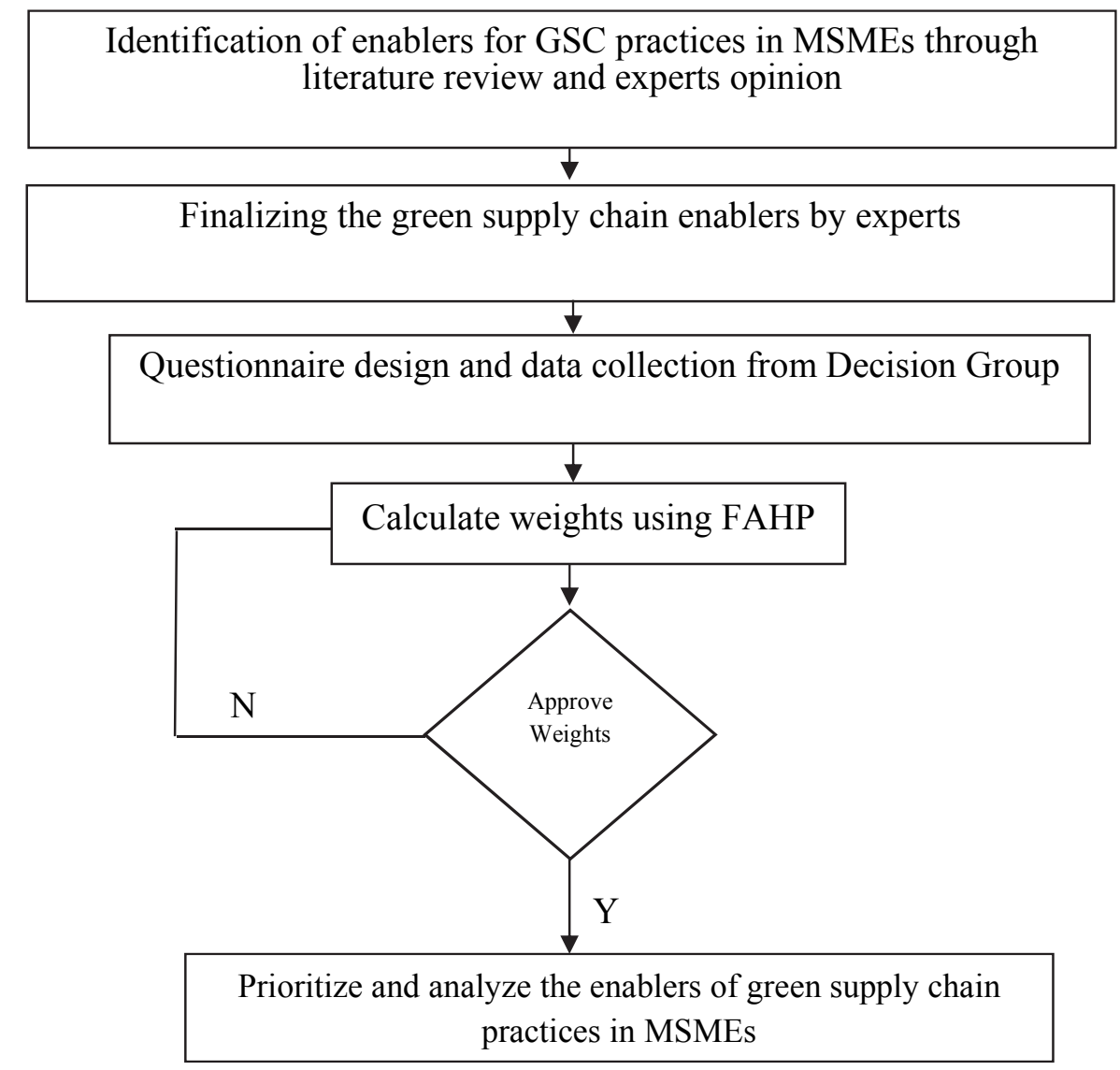

Fig. 1. Proposed FAHP methodology for GSC management enablers in MSMEs

\subsection{Fuzzy AHP}

The AHP methodology developed by Satty (1980) is a pioneering approach used widely in multi criteria decision making problems in management as well as other fields. However potent this approach is but it still suffers from limitations especially due to its crisp judgement scale being used which lacks subjective judgements. As the results are obtained by experts which often suffers from imprecise judgements due to ambiguity in giving a crisp value to a particular set of variables in question, to overcome this limitation Chang (1996) developed fuzzy extent analysis which involves using linguistic variables for making judgement. This approach has been used widely in decision making problems (Chan \& Kumar, 2007; Mangla et al., 2015; Prakash \& Barua, 2015, 2016).

\section{Table 2}

TFN for comparison of enablers in linguistic terms

\begin{tabular}{lc}
\hline Linguistic variables for comparison & Corresponding TFN \\
\hline Equal represented by E & $(1,1,1)$ \\
Very Low represented by VL & $(1,2,3)$ \\
Low represented by L & $(2,3,4)$ \\
Medium represented by M & $(3,4,5)$ \\
High represented by H & $(4,5,6)$ \\
Very High represented by VH & $(5,6,7)$ \\
Excellent represented by EX & $(7,8,9)$ \\
\hline
\end{tabular}


In Chang's fuzzy AHP extent analysis for each variable $\mathrm{g}_{\mathrm{i}}$ is carried out. The values for each variable in problem is obtained in extent analysis using following notations:

$M_{g_{i}}^{1}, M_{g_{i}}^{2}, M_{g_{i}}^{3}, \ldots \ldots \ldots \ldots \ldots \ldots, M_{g_{i}}^{m}$,

where $\mathrm{i}=1,2,3,4,5, \ldots \ldots \ldots \mathrm{n}$ and $\mathrm{j}=1,2,3,4,5, \ldots \ldots \ldots \mathrm{m}$ are TFN assigned in analysis. The steps of Chang's extent fuzzy AHP methodology are given as follows:

Step 1: The fuzzy synthetic extent value $\left(E_{i}\right)$ with respect to the $i^{\text {th }}$ criterion is defined as,

$$
E_{i}=\sum_{j=1}^{m} M_{g_{i}}^{j} \times\left[\sum_{i=1}^{n} \sum_{j=1}^{m} M_{g_{i}}^{j}\right]^{-1}
$$

where,

$\sum_{j=1}^{m} M_{g_{i}}^{j}=\left(\sum_{j=1}^{m} a_{i j}, \sum_{j=1}^{m} b_{i j}, \sum_{j=1}^{m} c_{i j}\right)$

$\left[\sum_{i=1}^{n} \sum_{j=1}^{m} M_{g_{i}}^{j}\right]^{-1}=\left(\frac{1}{\sum_{i=1}^{n} \sum_{j=1}^{m} a_{i j}}, \frac{1}{\sum_{i=1}^{n} \sum_{j=1}^{m} b_{i j}}, \frac{1}{\sum_{i=1}^{n} \sum_{j=1}^{m} c_{i j}}\right)$

where $(\mathrm{a}, \mathrm{b}, \mathrm{c})=($ lower, most likely value and upper value respectively $)$

Step 2: The possibility degree of $E_{2}=\left(a_{2}, b_{2}, c_{2}\right) \geq E_{1}=\left(a_{1}, b_{1}, c_{1}\right)$ is defined as below; where $a \leq b \leq c$. $\mathrm{V}\left(\mathrm{E}_{2} \geq \mathrm{E}_{1}\right)=\sup _{\mathrm{y} \geq \mathrm{x}}\left[\min \left(\mu_{\mathrm{E}_{1}}(x), \mu_{E_{2}}(\mathrm{y})\right]\right.$

and $\mathrm{x}$ and $\mathrm{y}$ denotes respective membership function value. The above relation can also be expressed as follows:

$$
V\left(E_{2} \geq E_{1}\right)=\left\{\begin{array}{cl}
1 & \text { if } b_{2} \geq b_{1} \\
0 & \text { if } a_{1} \geq c_{2} \\
\frac{a_{1}-c_{2}}{\left(\left(b_{2}-c_{2}\right)-\left(b_{1}-a_{1}\right)\right)}=\mu d \text { otherwise }
\end{array}\right.
$$

For comparison between $E_{1}$ and $E_{2}$ we need to determine $V\left(E_{1} \geq E_{2}\right)$ and $V\left(E_{2} \geq E_{1}\right)$.

Step 3: A convex fuzzy number $\mathrm{E}$ to be greater than $l$ convex fuzzy numbers $E_{i}(i=1,2, \ldots . ., l)$ can be defined by:

$\mathrm{V}\left(\mathrm{E} \geq \mathrm{E}_{1}, \mathrm{E}_{2}, \ldots, \mathrm{E}_{1}\right)=\mathrm{V}\left[\left(\mathrm{E} \geq \mathrm{E}_{1}\right)\right.$ and $\left.\left(\mathrm{E} \geq \mathrm{E}_{2}\right) \ldots\left(\mathrm{E} \geq \mathrm{E}_{1}\right)\right]=\operatorname{minV}\left(\mathrm{E} \geq \mathrm{E}_{\mathrm{i}}\right), \mathrm{i}=1,2, \ldots, 1$

Suppose that

$$
\mathrm{p}^{\prime}\left(\mathrm{A}_{\mathrm{i}}\right)=\min \mathrm{V}\left(\mathrm{E}_{\mathrm{i}} \geq \mathrm{E}_{\mathrm{l}}\right)
$$

For $1=1,2, \ldots, n, 1 \neq i$, and weight vectors are given in Eq. (4) as,

$$
\mathrm{W}^{\prime}=\left(\mathrm{p}^{\prime}\left(\mathrm{A}_{1}\right), \mathrm{p}^{\prime}\left(\mathrm{A}_{2}\right), \ldots \ldots . . \mathrm{p}^{\prime}\left(\mathrm{A}_{\mathrm{m}}\right)\right)^{\mathrm{T}}
$$

Step 4: After normalization, the normalized weight vectors can be obtained in Eq. (5) as,

$$
\mathrm{W}=\left(\mathrm{p}\left(\mathrm{A}_{1}\right), \mathrm{p}\left(\mathrm{A}_{2}\right), \ldots \ldots ., \mathrm{p}\left(\mathrm{A}_{\mathrm{m}}\right)\right)^{\mathrm{T}}
$$




\section{Results}

The value of fuzzy synthetic extent is calculated from fuzzy pair wise comparison matrix by using the Eq. (1). For illustration purpose, the calculation procedure is demonstrated for the green supply chain management practices enablers as discussed in Table 1. Let fuzzy synthetic values with respect to seven innovation capability factors are denoted by TA, TMC, RRE, GPS, SI, GSR and CA (See Table 1).

$$
\begin{aligned}
& T A=\sum_{j=1}^{m} M_{g_{1}}^{j}=(1,1,1)+(0.17,0.20,0.25)+(0.17,0.20,0.25)+(3,4,5)+(1,2,3) \\
& \quad+(0.11,0.13,0.14)+(3,4,5) \\
& =(8.45,11.53,14.64)
\end{aligned}
$$

Similarly,

$$
\begin{aligned}
& \text { TMC }=(16.20,21.25,26.33) \quad R R E=(11.51,14.62,17.78) \quad G P S=(9.71,11.87,14.11) \\
& S I=(11.06,13.50,16.66) \quad G S R=(16.31,20.37,24.45) \quad C A=(10,12.42,15.53) \\
& {\left[\sum_{i=1}^{n} \sum_{j=1}^{m} M_{g_{i}}^{j}\right]^{-1}=[(83.24),(105.56),(129.50)]^{-1}} \\
& A_{i}=\sum_{j=1}^{m} M_{g_{i}}^{j} \times\left[\sum_{i=1}^{n} \sum_{j=1}^{m} M_{g_{i}}^{j}\right]^{-1} \\
& T A=(8.45,11.53,14.64) *[(83.24),(105.56),(129.50)]^{-1}=(0.065,0.109,0.176) \\
& \operatorname{Similarly} T M C=(16.20,21.25,26.33) *[(83.24),(105.56),(129.50)]^{-1} \\
& \text { RRE }=(11.51,14.62,17.78) *[(83.24),(105.56),(129.50)]^{-1}=(0.089,0.138,0.214) \\
& \operatorname{GPS}=(9.71,11.87,14.11) *[(83.24),(105.56),(129.50)]^{-1}=(0.075,0.112,0.170) \\
& S I=(11.06,13.50,16.66) *[(83.24),(105.56),(129.50)]^{-1}=(0.085,0.128,0.200) \\
& G S R=(16.31,20.37,24.45) *[(83.24),(105.56),(129.50)]^{-1}=(0.126,0.193,0.294) \\
& C A=(10,12.42,15.53) *[(83.24),(105.56),(129.50)]^{-1}=(0.077,0.118,0.187)
\end{aligned}
$$

The degree of possibility of $T A \geq T M C$ can be calculated using Eq. (2) as shown below, $T A \geq T M C=1$ and $T M C \geq T A=\frac{0.125-0.176}{(0.109-0.176)-(0.201-0.125)}=0.355$

Similarly other calculations have been done by same procedure, by using the Eq. (2), V values computes are represented in Table 4.

Using Eq. (3) minimum degree of possibility is computes, $m(T A)=\min V(T A \geq T M C, T A \geq R R E, T A \geq G P S, T A \geq S I, T A \geq S I, T A \geq G S R, T A \geq C A$ $m(T A)=\min (0.355,0.748,0.969,0.829,0.374,0.921,0.355)=0.355$

Similarly all the other values are given as, $m(T M C)=1, m(R R E)=0.585, m(G P S)=0.026, m(S I)=0.505, m(G S R)=0.953, m(C A)$ $=0.424$

Then the weight vector is given as per Eq. (4) by:

$\mathrm{W}_{\mathrm{p}}=(0.355,1,0.585,0.026,0.505,0.953,0.424)^{T}$ 
After normalization of $\mathrm{W}_{\mathrm{p}}$, we get final weight vectors as per Eq. (5) as,

$\mathrm{W}=(0.092,0.260,0.152,0.007,0.131,0.248,0.110)^{T}$

The final ranking done as per normalized weight vector for GSC management enabler practices is given in Table 5.

Table 3

Fuzzy comparison matrix for green supply chain management enablers

\begin{tabular}{lccccccc}
\hline & TA & TMC & RRE & GPS & SI & GSR & CA \\
\hline TA & $1,1,1$ & $0.17,0.20,0.25$ & $0.17,0.20,0.25$ & $3,4,5$ & $1,2,3$ & $0.11,0.13,0.14$ & $3,4,5$ \\
TMC & $4,5,6$ & $1,1,1$ & $4,5,6$ & $0.20,0.25,0.33$ & $1,2,3$ & $5,6,7$ & $1,2,3$ \\
RRE & $4,5,6$ & $0.17,0.20,0.25$ & $1,1,1$ & $3,4,5$ & $3,4,5$ & $0.20,0.25,0.33$ & $0.14,0.17,0.20$ \\
GPS & $0.20,0.25,0.33$ & $3,4,5$ & $0.20,0.25,0.33$ & $1,1,1$ & $0.14,0.17,0.20$ & $0.17,0.20,0.25$ & $5,6,7$ \\
SI & $0.33,0.50,1$ & $0.33,0.50,1$ & $0.20,0.25,0.33$ & $5,6,7$ & $1,1,1$ & $4,5,6$ & $0.20,0.25,0.33$ \\
GSR & $7,8,9$ & $0.14,0.17,0.20$ & $3,4,5$ & $4,5,6$ & $0.17,0.20,0.25$ & $1,1,1$ & $1,2,3$ \\
CA & $0.20,0.25,0.33$ & $0.33,0.50,1$ & $5,6,7$ & $0.14,0.17,0.20$ & $3,4,5$ & $0.33,0.50,1$ & $1,1,1$ \\
\hline
\end{tabular}

Table 4

$\mathrm{V}$ Values for enablers of GSCM

\begin{tabular}{lccccccc}
\hline & TA & TMC & RRE & GPS & SI & GSR & CA \\
\hline TA & & 1.000 & 1.000 & 1.000 & 1.000 & 1.000 & 1.000 \\
TMC & 0.355 & & 0.585 & 0.333 & 0.505 & 0.953 & 0.424 \\
RRE & 0.748 & 1.000 & & 0.026 & 0.913 & 1.000 & 0.824 \\
GPS & 0.969 & 1.000 & 1.000 & & 1.000 & 1.000 & 1.000 \\
SI & 0.829 & 1.000 & 1.000 & 0.845 & & 1.000 & 0.908 \\
GSR & 0.374 & 1.000 & 0.617 & 0.351 & 0.533 & & 0.813 \\
CA & 0.921 & 1.000 & 1.000 & 0.947 & 1.000 & 1.000 & \\
\hline
\end{tabular}

Table 5

Final ranking of GSCM enablers

\begin{tabular}{lcc}
\hline GSCM Enablers & Final Weights & Rank \\
\hline Technological advancements (TA) & 0.092 & 6 \\
Top management commitment and finance (TMC) & 0.260 & 1 \\
Recycling and reuse efforts (RRE) & 0.152 & 3 \\
Green procurement strategies (GPS) & 0.007 & 7 \\
Supplier involvement (SI) & 0.131 & 4 \\
Government support and regulation (GSR) & 0.248 & 2 \\
Customer awareness (CA) & 0.110 & 5 \\
\hline
\end{tabular}

\section{Discussion and Managerial Implications}

Fuzzy AHP multi criteria decision making approach has been employed to rank the enablers for GSC management practices in MSMEs. The enablers have been ranked as follows $\mathrm{TMC}>\mathrm{GSR}>\mathrm{RRE}>\mathrm{SI}>\mathrm{CA}>\mathrm{TA}>\mathrm{GPS}$ as shown in Table 5 . For the particular case in study experts have ranked Top Management Commitment and Finance (TMC) as most prominent enabler for GSCM implementation. This finding is also in line with past literature which emphasizes the importance of top management in transforming a supply chain to go green. Support of top management is prerequisite for implementing GSC practices in organization (Digalwar \& Metri, 2004) as they are responsible for managing finance, allocation of resources and bringing necessary technology into organization (Mudgal et al., 2009; Luthra et al., 2013). Second important enabler is Government Support and 
Regulations (GSR) with a weight of 0.248. Govindan et al. (2016) also supports this finding, government can force strict legislations and implement policies favourable for implementation of green manufacturing practices by industries. Government can support in terms of incentives for manufacturing organizations implementing GSCM practices (Sandeep et al., 2013). Third important enabler identified through this study is Recycling and Reuse Efforts (RRE). The organizations can benefit to a great deal by implementing practices that help dispose of or recycle the waste produced at each stage of manufacturing. Reusing the byproducts also benefits the organizations economically (Govindan et al., 2014; Prakash \& Barua, 2015; Rehman et al., 2015).

Managers of organizations have very important implications from this study. Firstly GSCM implementation in MSMEs depends on the top managers or in case of MSMEs the owners i.e. entrepreneurs of the organizations. Since all the decision making power vests with the owner of the organization, they should be motivated enough and should be aware of the benefits of converting to green supply chain. Finance is often the most prominent constraint for small organizations to convert their system and owners of these organizations through their efforts and links can acquire finance either from government in the form of various schemes or from their peers working in other organizations which might even include large organizations. Second important implication is that mangers must realize the role of government organizations in achieving the target of green conversion of their supply chain. Government can provide subsidies through its various schemes and also tax benefits and incentives to convert the system. Managers must coordinate with government to get the benefits from such schemes. Moreover government first of all needs to make owners of small organizations about economic and environmental benefits from implementing green supply chain practices, this can be done through seminars, promotional programs and also running special training for employees of these organizations to learn to implement green practices. Third important implication is the implementation of recycling and reuse efforts by the mangers at their organizations. Managers must realize the economic benefits from reusing the byproducts obtained at each stage and also they need to make effort for recycling the waste so that minimum waste is generate in the environment. In this aspect the government can also support by setting up recycling plants near to clusters of small organizations so as to help them mitigate the risks of waste generated through mass manufacturing. Also managers need to upgrade their technology so that they generate less waste and economically manufacture their products with minimum impact to environment.

\section{Sensitivity Analysis}

Sensitivity analysis has been done to check the biasness in results and to filter out any effect of enabler with highest weights on other enablers in study. Mangla et al. (2015); Prakash and Barua (2015) and Vishwakarma et al. (2016) suggested use of sensitivity analysis by varying weights of all the factors in study in proportion to variation in weight of top ranked enabler. Table 6 indicates the weights of all the enablers when weight of Top Management commitment is varied from 0.1 to 0.9 , the weights of all the enablers are varied accordingly.

Table 6

Variation in weights value for all enablers when varying TMC weight value

\begin{tabular}{lllllllllll}
\hline TMC & 0.260 & 0.100 & 0.200 & 0.300 & 0.400 & 0.500 & 0.600 & 0.700 & 0.800 & 0.900 \\
GSR & 0.248 & 0.301 & 0.268 & 0.234 & 0.201 & 0.167 & 0.134 & 0.100 & 0.067 & 0.033 \\
RRE & 0.152 & 0.185 & 0.164 & 0.144 & 0.123 & 0.103 & 0.082 & 0.062 & 0.041 & 0.021 \\
SI & 0.131 & 0.160 & 0.142 & 0.124 & 0.106 & 0.089 & 0.071 & 0.053 & 0.035 & 0.018 \\
CA & 0.110 & 0.134 & 0.119 & 0.104 & 0.089 & 0.074 & 0.059 & 0.045 & 0.030 & 0.015 \\
TA & 0.092 & 0.112 & 0.100 & 0.087 & 0.075 & 0.062 & 0.050 & 0.037 & 0.025 & 0.012 \\
GPS & 0.007 & 0.008 & 0.007 & 0.006 & 0.005 & 0.005 & 0.004 & 0.003 & 0.002 & 0.001 \\
\hline Sum & 1.000 & 1.000 & 1.000 & 1.000 & 1.000 & 1.000 & 1.000 & 1.000 & 1.000 & 1.000 \\
\hline
\end{tabular}

Table 7 indicates the ranking of these enablers based on weights obtained in table 6 . It can be seen in figure 2 and 3 as well that when TMC weight is changed to 0.1 its ranking becomes 6 and first rank is 
acquired by GSR, similarly when weight of TMC is varied to 0.2 its rank becomes 5 and first rank is again acquired by GSR. After that with increase in weightage of TMC from 0.2 to 0.9 it acquires rank 1 and rank of all the enablers is same and also last rank is always acquired by GPS. The result of sensitivity analysis indicates that the results obtained through fuzzy AHP are free from any bias and results are consistent even if there is variation in weights of one enabler.

\section{Table 7}

Ranking for enablers by sensitivity analysis when Top Management Commitment varies from 0.1 to 0.9

\begin{tabular}{lcccccccccc}
\hline & 0.1 & 0.2 & 0.260 (Normal) & 0.3 & 0.4 & 0.5 & 0.6 & 0.7 & 0.8 & 0.9 \\
\hline TA & 6 & 5 & 6 & 6 & 6 & 6 & 6 & 6 & 6 & 6 \\
TMC & 2 & 6 & 1 & 1 & 1 & 1 & 1 & 1 & 1 & 1 \\
RRE & 3 & 2 & 3 & 3 & 3 & 3 & 3 & 3 & 3 & 3 \\
GPS & 7 & 7 & 7 & 7 & 7 & 7 & 7 & 7 & 7 & 7 \\
SI & 4 & 3 & 4 & 4 & 4 & 4 & 4 & 4 & 4 & 4 \\
GSR & 1 & 1 & 2 & 2 & 2 & 2 & 2 & 2 & 2 & 2 \\
CA & 5 & 4 & 5 & 5 & 5 & 5 & 5 & 5 & 5 & 5 \\
\hline
\end{tabular}

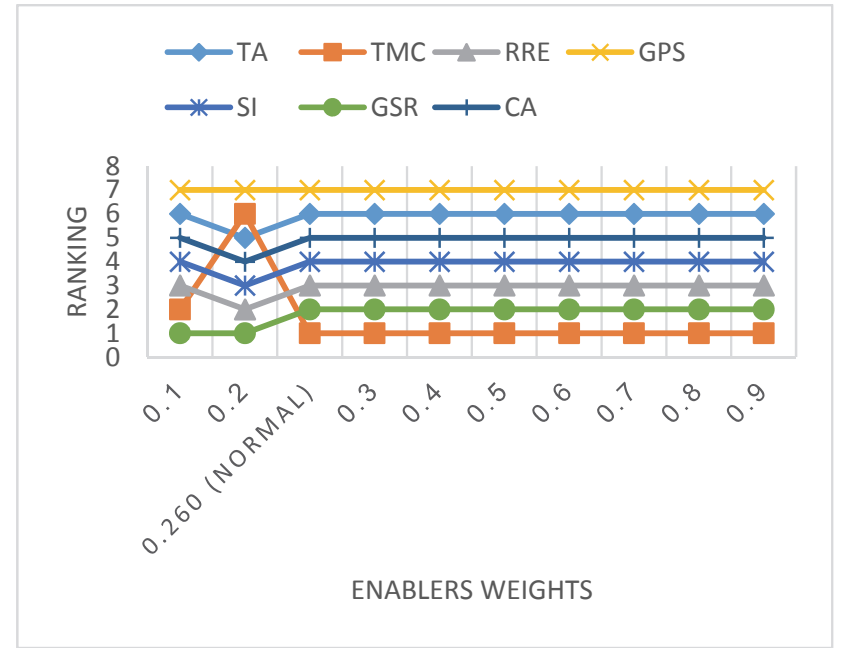

Fig. 2. Ranking of enablers based on sensitivity analysis

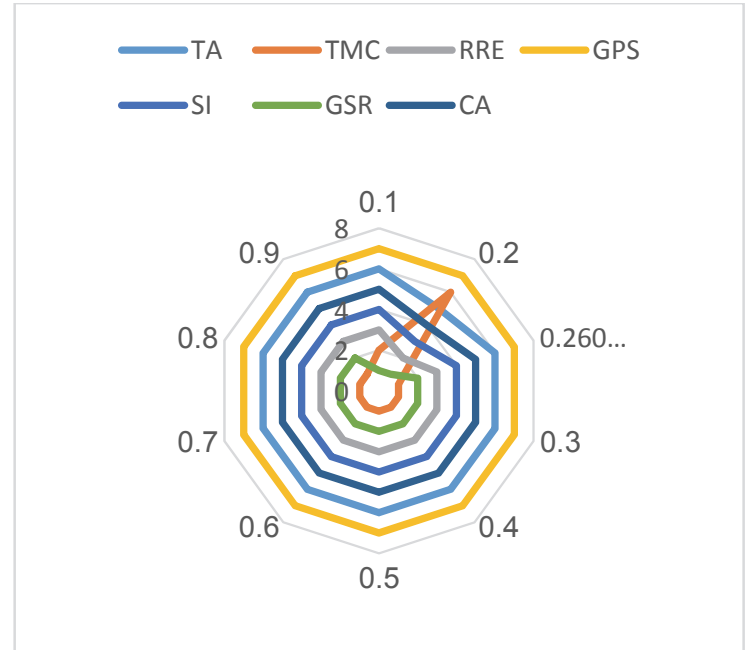

Fig. 3. Sensitivity analysis results

\section{Conclusions}

The study has identified three important enablers for GSC implementation in MSMEs viz. Top Management Commitment and Finance (TMC), Government Support and Regulations (GSR) and Recycling and Reuse Efforts (RRE). Small organizations continuously strive to survive the increasing global competition and requires innovative efforts to stay afloat. Practicing green supply chain practices in their organization is one way to compete with their competitors. The benefits of converting to green are immense but small organizations first need to be made aware of these benefits so that owners of these organizations enthusiastically participate in implementation of green supply chain. Role of top managers (owners) is of huge prominence. Owners of small organizations need to acquire funds for implementation of green technology, they can collaborate with large organizations and government to upgrade technology required for green supply chain implementation and on the other front government can support these organizations through innovative programs to fund them for green conversion efforts by setting waste management units, training employees, marketing the benefits thus increasing awareness among customers for green products. It is noteworthy that all these enablers are interrelated and working on one will lead to improvement in other. 


\section{Limitations}

Current study suffers from few limitations. Major limitation is that it considers only seven important enablers for green supply chain implementation practices, however many more enablers can be explored through extensive review of literature. Second it is based on experts' opinion, the results can be validated by conduction a study on large sample. Also results can be cross verified by using other MCDM techniques like Fuzzy TOPSIS, PROMTHEE, and VIKOR. Finally interrelationship among enablers can also be studied using ISM or DEMATEL methodologies.

\section{References}

Bansal, P., \& Roth, K. (2000). Why companies go green: A model of ecological responsiveness. Academy of management journal, 43(4), 717-736.

Baylis, R., Connell, L., \& Flynn, A. (1998). Sector variation and ecological modernization: towards an analysis at the level of the firm. Business Strategy and the Environment, 7(3), 150-161.

Beamon, B. M. (1999). Designing the green supply chain. Logistics information management, 12(4), 332-342.

Bhetja, A. K., \& Babbar, R. (2011). Study of green supply chain management in the Indian manufacturing industries: a literature review cum an analytical approach for the measurement of performance, International Journal of computational Engineering \& Management, Vol. 13, pp. 84-99.

Björklund, M., Martinsen, U., \& Abrahamsson, M. (2012). Performance measurements in the greening of supply chains. Supply Chain Management: An International Journal, 17(1), 29-39.

Carter, C. R., \& Dresner, M. (2001). Purchasing's role in environmental management: cross-functional development of grounded theory. Journal of Supply Chain Management, 37(2), 12-27.

Carter, C. R., \& Rogers, D. S. (2008). A framework of sustainable supply chain management: moving toward new theory. International journal of physical distribution \& logistics management, 38(5), 360-387.

Chan, F. T., \& Kumar, N. (2007). Global supplier development considering risk factors using fuzzy extended AHP-based approach. Omega, 35(4), 417-431.

Chang, D. Y. (1996). Applications of the extent analysis method on fuzzy AHP. European journal of operational research, 95(3), 649-655.

Chien, M. K., \& Shih, L. H. (2007). An empirical study of the implementation of green supply chain management practices in the electrical and electronic industry and their relation to organizational performances. International Journal of Environmental Science and Technology:(IJEST), 4(3), 383.

Dhull, S., \& Narwal, M. (2016). Drivers and barriers in green supply chain management adaptation: A state-ofart review. Uncertain Supply Chain Management, 4(1), 61-76.

Diabat, A., \& Govindan, K. (2011). An analysis of the drivers affecting the implementation of green supply chain management. Resources, Conservation and Recycling, 55(6), 659-667.

Diabat, A., Khodaverdi, R., \& Olfat, L. (2013). An exploration of green supply chain practices and performances in an automotive industry. The International Journal of Advanced Manufacturing Technology, 68(1-4), 949961.

Digalwar, A. K., \& Metri, B. A. (2004). Performance measurement framework for world class manufacturing. International Journal of Applied Management and Technology, 3(2), 83-101.

Eiadat, Y., Kelly, A., Roche, F., \& Eyadat, H. (2008). Green and competitive? An empirical test of the mediating role of environmental innovation strategy. Journal of World Business, 43(2), 131-145.

Eltayeb, T. K., Zailani, S., \& Ramayah, T. (2011). Green supply chain initiatives among certified companies in Malaysia and environmental sustainability: Investigating the outcomes. Resources, conservation and recycling, 55(5), 495-506.

Eniola, A., Entebang, H., \& Sakariyau, O. B. (2015). Small and medium scale business performance in Nigeria: Challenges faced from an intellectual capital perspective. International Journal of Research Studies in Management, 4(1).

Govindan, K., Kaliyan, M., Kannan, D., \& Haq, A. N. (2014). Barriers analysis for green supply chain management implementation in Indian industries using analytic hierarchy process. International Journal of Production Economics, 147, 555-568.

Govindan, K., Muduli, K., Devika, K., \& Barve, A. (2016). Investigation of the influential strength of factors on adoption of green supply chain management practices: An Indian mining scenario. Resources, Conservation and Recycling, 107, 185-194. 
Green, K., Morton, B., \& New, S. (1996). Purchasing and environmental management: interactions, policies and opportunities. Business Strategy and the Environment, 5(3), 188-197.

Gupta, H., \& Nanda, T. (2015). A quantitative analysis of the relationship between drivers of innovativeness and performance of MSMEs. International Journal of Technology, Policy and Management, 15(2), 128-157.

Gupta, H; Bisen, J; Kumar, S and Das, S (2015). Applying TOPSIS analysis for identification of most relevant critical success factor for TQM implementation in Indian MSMEs, International Journal of Applied Engineering Research, 10(54), 119-126.

Gupta, H; Das, S; Kumar, S and Bisen, J (2016). Developing a model of critical success factors for TQM implementation in MSMEs in India and their effect on internal and external quality of organization. Selected for publication in International Journal of Business Excellence (in press).

Hassan, M. G., Abidin, R., Nordin, N., \& Yusoff, R. Z. (2016). GSCM Practices and Sustainable Performance: A Preliminary Insight. Journal of Advanced Management Science Vol, 4(5), 430-434.

Ilgin, M. A., \& Gupta, S. M. (2010). Environmentally conscious manufacturing and product recovery (ECMPRO): a review of the state of the art. Journal of environmental management, 91(3), 563-591.

Kharub, M. \& Sharma, R.K. (2015) Investigating the role of CSF's for successful implementation of quality management practices in MSMEs, International Journal of System Assurance Engineering \& Management, DOI 10.1007/s13198-015-0394-y.

Lee, S. Y. (2008). Drivers for the participation of small and medium-sized suppliers in green supply chain initiatives. Supply Chain Management: An International Journal, 13(3), 185-198.

Lee, S. Y. (2008). Drivers for the participation of small and medium-sized suppliers in green supply chain initiatives. Supply Chain Management: An International Journal, 13(3), 185-198.

Lee, V. H., Ooi, K. B., Chong, A. Y. L., \& Seow, C. (2014). Creating technological innovation via green supply chain management: An empirical analysis. Expert Systems with Applications, 41(16), 6983-6994.

Lin, C. Y., \& Ho, Y. H. (2008). An empirical study on logistics service providers' intention to adopt green innovations. Journal of Technology Management \& Innovation, 3(1), 17-26.

López-Gamero, M. D., Molina-Azorín, J. F., \& Claver-Cortes, E. (2011). The relationship between managers' environmental perceptions, environmental management and firm performance in Spanish hotels: a whole framework. International Journal of Tourism Research, 13(2), 141-163.

Luthra, S., Kumar, V., Kumar, S., \& Haleem, A. (2011). Barriers to implement green supply chain management in automobile industry using interpretive structural modeling technique: An Indian perspective. Journal of Industrial Engineering and Management, 4(2), 231-257.

Mallidis, I., \& Vlachos, D. (2010, October). A Framework for green supply chain management. In 1st Olympus International Conference on Supply Chain (pp. 1-2).

Mangla, S. K., Kumar, P., \& Barua, M. K. (2015). Risk analysis in green supply chain using fuzzy AHP approach: a case study. Resources, Conservation and Recycling, 104, 375-390.

Manhas, V, Gupta, H and Gupta, P (2015). Developing and Validating Critical Success Factors of TQM Implementation in MSMEs of Punjab in India" accepted for publication in International Journal of Indian Culture and Business Management, 11(4), 405-420.

Matus, K. J., Clark, W. C., Anastas, P. T., \& Zimmerman, J. B. (2012). Barriers to the implementation of green chemistry in the United States. Environmental science \& technology, 46(20), 10892-10899.

Min, H., \& Galle, W. P. (2001). Green purchasing practices of US firms. International Journal of Operations \& Production Management, 21(9), 1222-1238.

Mudgal, R. K., Shankar, R., Talib, P., \& Raj, T. (2009). Greening the supply chain practices: an Indian perspective of enablers' relationships. International Journal of Advanced Operations Management, 1(2-3), 151-176.

Mudgal, R. K., Shankar, R., Talib, P., \& Raj, T. (2010). Modelling the barriers of green supply chain practices: an Indian perspective. International Journal of Logistics Systems and Management, 7(1), 81-107.

Nanda, T., Gupta, H., Kharub, M., \& Singh, N. (2013). Diagnostics for pretesting questionnaires: a comparative analysis. International Journal of Technology, Policy and Management, 13(1), 67-79.

New, S. (2000). Buying the environment: the multiple meanings of green supply. The business of greening, 3353.

Pawanchik A, \& Sulaiman S (2010) In search of InnovAsian: the Malaysian innovation climate report. Alpha Catalyst Consulting.

Prakash, C., \& Barua, M. K. (2015). Integration of AHP-TOPSIS method for prioritizing the solutions of reverse logistics adoption to overcome its barriers under fuzzy environment. Journal of Manufacturing Systems, 37, 599-615. 
Prakash, C., \& Barua, M. K. (2016). An analysis of integrated robust hybrid model for third-party reverse logistics partner selection under fuzzy environment. Resources, Conservation and Recycling, 108, 63-81.

Qi, G. Y., Shen, L. Y., Zeng, S. X., \& Jorge, O. J. (2010). The drivers for contractors' green innovation: an industry perspective. Journal of Cleaner Production, 18(14), 1358-1365.

Ravi, V., \& Shankar, R. (2005). Analysis of interactions among the barriers of reverse logistics. Technological Forecasting and Social Change, 72(8), 1011-1029.

Rehman, M. A. A., Aneyrao, T. A., \& Shrivastava, R. L. (2015). Identification of critical success factors in Indian automobile industry: a GSCM approach. International Journal of Process Management and Benchmarking, 5(2), 229-245.

Rha, J. S. (2010). The impact of green supply chain practices on supply chain performance.

Saaty, T.L. (1980) Analytic Hierarchy Processes, McGraw-Hill, New York

Sandeep, K., Sanjay, K., Pardeep, G., \& Abid, H. (2013). Analysis of interdependence among the enablers of green concept implementation in Indian automobile supply chain. Journal of Engineering Research and Studies, 4(2), 05-11.

Sarkis, J. (2003). A strategic decision framework for green supply chain management. Journal of cleaner production, 11(4), 397-409.

Sarkis, J., Zhu, Q., \& Lai, K. H. (2011). An organizational theoretic review of green supply chain management literature. International Journal of Production Economics, 130(1), 1-15.

Sarkis, J., Zhu, Q., \& Lai, K. H. (2011). An organizational theoretic review of green supply chain management literature. International Journal of Production Economics, 130(1), 1-15.

Sharma, R. K., \& Kharub, M. (2015). Qualitative and quantitative evaluation of barriers hindering the growth of MSMEs. International Journal of Business Excellence, 8(6), 724-747.

Soda, S., Sachdeva, A., \& Garg, R. K. (2015). GSCM: practices, trends and prospects in Indian context. Journal of Manufacturing Technology Management, 26(6), 889-910.

Srivastava, S. K. (2007). Green supply-chain management: a state-of-the-art literature review. International journal of management reviews, $9(1), 53-80$.

Tsoulfas, G.T. and Pappis, C.P., (2006) 'Environmental principles applicable to supply chains design and operation', Journal of Cleaner Production, Vol.14, pp. 1593-1602.

Vishwakarma,V., Prakash, C. and Barua, M.K. (xxxx) 'A fuzzy-based multi criteria decision making approach for supply chain risk assessment in Indian pharmaceutical industry', Int. J. Logistics Systems and Management, Vol. X, No. Y, pp.xxx-xxx.

Wu, G. C., Cheng, Y. H., \& Huang, S. Y. (2010). The study of knowledge transfer and green management performance in green supply chain management. African Journal of Business Management, 4(1), 44.

$\mathrm{Yu}, \mathrm{L}$. C. (2007). Adoption of green supply in Taiwan logistic industry. Journal of management study, 2(2), 9098.

Zhu, Q., \& Sarkis, J. (2006). An inter-sectoral comparison of green supply chain management in China: drivers and practices. Journal of cleaner production, 14(5), 472-486.

Zhu, Q., Dou, Y., \& Sarkis, J. (2010). A portfolio-based analysis for green supplier management using the analytical network process. Supply Chain Management: An International Journal, 15(4), 306-319.

Zhu, Q., Sarkis, J., \& Lai, K. H. (2007a). Green supply chain management: pressures, practices and performance within the Chinese automobile industry. Journal of Cleaner Production, 15(11), 1041-1052.

Zhu, Q., Sarkis, J., \& Lai, K. H. (2007b). Initiatives and outcomes of green supply chain management implementation by Chinese manufacturers. Journal of environmental management, 85(1), 179-189.

Zhu, Q., Sarkis, J., \& Lai, K. H. (2008). Confirmation of a measurement model for green supply chain management practices implementation. International journal of production economics, 111(2), 261-273.

Zhu, Q., Sarkis, J., \& Lai, K. H. (2012). Green supply chain management innovation diffusion and its relationship to organizational improvement: An ecological modernization perspective. Journal of Engineering and Technology Management, 29(1), 168-185.

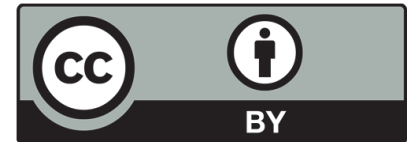

(C) 2016 by the authors; licensee Growing Science, Canada. This is an open access article distributed under the terms and conditions of the Creative Commons Attribution (CC-BY) license (http://creativecommons.org/licenses/by/4.0/). 